\title{
NOMADS AND THE STRUGGLE FOR A LEGAL IDENTITY
}

\author{
HEATHER ALEXANDER*
}

Over the past century, governments around the world have greatly expanded civil registration and the issuance of identity documents of all kinds. The process of identifying and registering individuals is sometimes called establishing their 'legal identity'. ${ }^{1}$ Establishing a legal identity is crucial for people to access many rights. ${ }^{2}$ It is also a basic prerequisite for establishing a nationality. A legal identity is also important for governments to surveil their populations.

Yet, as more research is done on the legal identity of nomadic and mobile peoples, ${ }^{3}$ it is emerging that establishing a legal identity is not easy for them, nor is it a panacea that automatically helps them access their rights. Instead, it can lead to their assimilation. ${ }^{4}$ This comment summarises my recent research into the establishment of legal identity for nomadic and mobile peoples, uncovering important and disturbing new insights into this fraught process. ${ }^{5}$

Problems with establishing the legal identity of nomads stretch back to the colonial period. ${ }^{6}$ The end of the colonial period saw the rapid introduction of laws creating identity documents and centralised registration around the world. However, the short time frame in which these systems were created meant that mass registration was in many cases never done and most rural peoples, including many nomads, entered decolonisation with no identity documents of any kind. Because nomads often lacked a fixed residence, colonial administrators struggled to register them and keep them within their designated, administrative zones. Meanwhile, colonial empires vested settled and urban rulers with enormous, centralised powers, including the power to issue documents, while marginalising nomadic leaders. Nomad territories, usually labelled by the colonial powers as

* Heather Alexander obtained her doctorate in law from Tilburg University in 2020. Her work focuses on nomads, nationality and statelessness. She has several years of experience working for the United Nations High Commissioner for Refugees in Africa, Asia and Europe. She lives in Montreal, Canada.

1 To establish a legal identity is to be recognised as a person before the law. See 'UN Legal Identity Agenda', United Nations Department of Economic and Social Affairs, Statistics Department (Web Page) <https://unstats.un.org/legal-identity-agenda/>. See also Transforming Our World: The 2030 Agenda for Sustainable Development, UN Doc A/RES/70/1 (21 October 2015) Target 16.9.

2 Universal Declaration of Human Rights, GA Res 217A (III), UN GAOR, UN Doc A/810 (10 December 1948) art 6; International Covenant on Civil and Political Rights, opened for signature 16 December 1966, 999 UNTS 171 (entered into force 23 March 1976) art 16

3 For a discussion of the use of the term nomad, see Heather Alexander, 'The Nationality and Statelessness of Nomadic Peoples under International Law' (PhD Dissertation, Tilburg University 2020) 17-21.

4 Heather Alexander, 'The Open Sky or a Brick-and-Mortar School? Statelessness, Education and Nomadic Children' in The World's Stateless Children (Report, Institution on Statelessness and Inclusion 2017) 248.

5 ibid.

6 European colonisation was a political and economic phenomenon marked by the invasion and domination of non-European societies by Europeans. It began in the 1500 s and continued in many parts of the world until the 1960s. 
'remote', were often divided by borders, calling into question the proper authority to register nomads.

In British North Borneo, for example, few inhabitants received documents or any official acknowledgement of their status until just before the end of the colonial period, leaving mass civil registration, including a determination of the status of populations in border zones, for the post-colonial period. ${ }^{7}$ In many Gulf states, British colonial administrators vested power to issue British documents with urban Sultans and Emirs, rather than nomadic Bedouin leaders. ${ }^{8}$ Urban rulers could establish legal identity and even issue British identity documents to groups over whom they arguably had no jurisdiction, like the Bedouin. ${ }^{9}$

In French West Africa, colonial administrators began registering the sedentary population following the enactment of the 1946 Constitution of the French Republic, ${ }^{10}$ but they administrated nomadic populations separately and struggled to control their movements. ${ }^{11}$ While separate administration appeared to offer nomads more autonomy, it left them out of the developing administrative state. According to the governor of French Soudan, which would become Mali, 'such [registration] ... could be accomplished only for the sedentary part of his population, step by step, and at high cost'. ${ }^{12}$

Colonial independence would see a continuation of problems for nomadic communities in establishing their legal identity, including widespread discrimination against nomads and the division of nomad territories by borders. ${ }^{13}$ Undocumented nomads risked being labelled as foreigners or as stateless persons. Registration committees set up by the Kuwaiti government, for example, closely interrogated Bedouin claims to Kuwaiti civil registration, even as the settled, urban population easily qualified under the law. ${ }^{14}$ Some Bedouin with documents showing that they owned property in Kuwait were prevented from registering. ${ }^{15}$

7 The Naturalisation Ordinance, Ordinance No 1 of 1931 (North Borneo), cited in Laurie Fransman (ed), Fransman's British Nationality Law (3 ${ }^{\text {rd }}$ edn, Bloomsbury 2011) 141, 697. See also North Borneo Cession Order in Council (1946) (United Kingdom); Mathews Thomas, 'Is Malaysia's Mykad the "One Card to Rule Them All"? The Urgent Need to Develop a Proper Legal Framework for the Protection of Personal Information in Malaysia' (2004) 28(2) Melbourne University Law Review 474.

8 John Harding, 'Matters Colonial, Consular and Curious' in Peter Hinchcliffe, John T Ducker, and Maria Holt (eds), Without Glory in Arabia: The British Retreat from Aden (Tauris 2013) 279,280 .

9 ibid 281-83.

10 See Constitution of the French Republic, Journal Officiel 28 October 1946 (France) arts 80-82.

11 ibid arts 76,78

12 Frederick Cooper, Citizenship between Empire and Nation: Remaking France and French Africa, 1945-1960 (Princeton University Press 2016) 154, citing the Governor of Sudan.

13 Kuwaiti independence was achieved by the termination of the Anglo-Kuwaiti Agreement of 1899 by the Kuwaiti Emir and Britain over a number of years, ending in 1961. James Crawford, The Creation of States in International Law (2 ${ }^{\text {nd }}$ edn, Oxford University Press 2006) 319. See also Michael Casey, The History of Kuwait (Greenwood Publishing Group 2007) 21.

14 Claire Beaugrand, Statelessness and Transnationalism in Northern Arabia: Biduns and State Building in Kuwait, 1959-2009 (PhD dissertation, London School of Economics 2010) 8184, 124-25. See also Farah al-Nakib, 'Revisiting Hadar and Badu in Kuwait: Citizenship, Housing, and the Construction of a Dichotomy’ (2014) 46(1) International Journal of Middle Eastern Studies 5, 12.

15 Beaugrand, Statelessness and Transnationalism (n 14) 124. See also Marie Lund-Johansen, Fighting for Citizenship in Kuwait (Masters Thesis, University of Oslo 2014) 25; Al-Nakib (n 14) 12. 
After colonial independence, registration in what is now Sabah, Malaysia, focused almost exclusively on settled Sama and Bajau villages, while ignoring the nomadic Sama Dilaut (Bajau Laut) population. This created a 'major division' at independence in Semporna between villagers and nomads. ${ }^{16}$ In 1972, the government instituted registration drives in rural areas but, unlike many settled groups, the Sama Dilaut did not have a recognised village headman who could vouch for their residence. ${ }^{17}$ In 2008 , the government issued identity documents to some stateless persons in Sabah, but this program made no attempt to assist the Sama Dilaut. ${ }^{18}$ Today, ID in Malaysia is critical and the introduction of biometric ID cards has made living undocumented in Sabah increasingly difficult. ${ }^{19}$ Many Sama Dilaut in Malaysia are treated as aliens even when using their traditional fishing zones, meaning that they had to register as temporary workers in order to practice their way of life. ${ }^{20}$

In some places, the question of legal identity for nomads is linked to bitter conflicts over belonging and inclusion, leading to armed conflict. For example, the Malian government swiftly enacted comprehensive legislation on civil registration following independence, ${ }^{21}$ but the question of Tuareg separatism and their inclusion in the Malian state would devolve into civil war by 1962, impeding Tuareg registration for generations. Armed conflict continues, despite reforms to the civil registration laws in 2006. ${ }^{22}$

The above paragraphs summarise some of the many problems nomads have had in obtaining a legal identity and some of the negative consequences caused by their lack of legal identity. Yet, crucially, obtaining a legal identity has not necessarily led to the protection of the human rights of nomads. In fact, in many places, a legal

16 Clifford Sather, The Sama Dilaut: Adaptation, History, and Fate in a Maritime Fishing Society of South-Eastern Sabah (Oxford University Press 1997) 87.

17 Tan Sri Datuk Amar Steve Shim Lip Kiong et al, Report of the Commission of Enquiry on Immigrants in Sabah: Presented to Seri Paduka Baginda Yang Di-Pertuan Agong (Royal Commission of Inquiry, 2012) 302.

18 Ismail Ali and Mohammad Raduan Mohd Ariff, 'Since Birth Till Death, What is their Status? A Case Study of the Sea Bajau in Pulau Mabul, Semporna' (2010) 1(1) Journal of Arts, Science and Commerce 156, 163.

19 Thomas (n 7) 474. See also Patrick Blanche, Nomades de la mer, Vezos, Bajaus, Mokens (Ibis Press 2008) 78; James Warren, The North Borneo Chartered Company's Administration of the Bajau, 1878-1909; The Pacification of a Maritime, Nomadic People (Ohio University Press 1971) 26; Fausto Barlocco, Identity and the State in Malaysia (Routledge 2014) 78.

20 Carol Warren, 'Consciousness in Social Transformation: The Sama Dilaut of East Malaysia' 5(3) Dialectical Anthropology 227 (1980) 88, 228.

21 In 1960, French Soudan, renamed Mali, became fully independent under the socialist Modibo Keïta. Loi No 60-14 du 20 juin 1960: proclamant solennellement l'indépendance nationale de la fédération du Mali [Law No 60-14 of 20 June 1960: Solemn Proclamation of the National Independence of the Federation of Mali] (Mali) 383. See also Décret No 014/PG$R M d u 09$ janvier 1988 portant institution et règlementation de la délivrance de la carte d'identité et de la carte consulaire [Decree No 014/PG-RM of 9 January 1988 Establishing and Regulating the Issuance of the Identity Card and the Consular Card] (Mali); Décret No 55-014/PG-RM du 9 Janvier 1988 [Decree No 55-014/PG-RM of 9 January 1988] (Mali); Loi No 06-040 du 11 août 2006 portant institution du numéro d'identification nationale des personnes physiques et morales [Law No 06-040 of 11 August 2006 Establishing the National Identification Number of Natural and Legal Persons] (Mali); Loi No 11-080 portant code des personnes et de la famille [Law No 11-080 on the Code of Persons and the Family], JORM Spécial (31 Jan 2012) (Mali) art 84.

22 Loi No 06-024 du 28 juin 2006 régissant l'État civil [Law No 06-024 of 28 June 2006 Governing Civil Status] (Mali). See also Michael Offermann, Les risques d'apatridie au Mali et pour les Maliens vivant à l'étranger en application des législations et pratiques relatives à la nationalité, au Mali et dans les pays d'accueil de Maliens (Report, UNHCR 2020) 14, 28-29, 33. 
identity for nomads has gone hand in hand with settlement and assimilation or with statelessness and exclusion. ${ }^{23}$ Between 1960 and 1987, the descendants of nomadic Bedouin in Kuwait who had no nationality papers were issued identity documents with the official status of bidoon jinsiyya, or 'without nationality', under a special administrative process. ${ }^{24}$ In 1965, the Kuwaiti government made issuance of a birth certificate compulsory, yet this only entrenched bidoon status for many former Bedouin. ${ }^{25}$ Other Bedouin were naturalised by the Kuwaiti government, but given an inferior nationality status in exchange for settlement in urban areas and service in the military or jobs at oil fields. ${ }^{26}$ The steady erosion of human rights for many former Bedouin and their descendants soon followed, accompanied by a rapid collapse of nomadism. ${ }^{27}$

As this comment has shown, obtaining a legal identity remains a serious problem for nomads in many countries. Solutions may include, for example, mobile registration clinics and other programs to ease registration for nomads 28 and eliminating bias against nomadism from civil registration laws, policies and procedures. Yet, as my recent research has also uncovered, establishing a legal identity has also negatively impacted many nomads, leading to their assimilation and raising serious questions of how legal identity and human rights intersect for nomads.

23 See generally Alexander, 'The Open Sky or a Brick-and-Mortar School?' (n 4).

24 Ang Nga Longva, 'Citizenship in the Gulf States: Conceptualization and Practice' in Nils August Butenschøn, Manuel Sarkis Hassassian and Uri Davis (eds), Citizenship and the State in the Middle East (Syracuse 2000) 187. See also Al-Nakib (n 14) 12.

25 Claire Beaugrand, Stateless in the Gulf: Migration, Nationality and Society in Kuwait (Tauris 2018) 88. See also Beaugrand, Statelessness and Transnationalism (n 14) 129.

26 Longva (n 24) 187. See also Gianluca Parolin, Citizenship in the Arab World (Amsterdam University Press 2009) 116; Shaul Yanai, The Political Transformation of Gulf Tribal States: Elitism and the Social Contract in Kuwait, Bahrain and Dubai: 1918-1970s (Sussex Academic Press 2014) 223-25; Greg Power, 'The Difficult Development of Parliamentary Politics in the Gulf' in David Held and Kristian Ulrichsen, The Transformation of the Gulf: Politics, Economics and the Global Order (Routledge 2012) 33. See also Jacqueline Ismael, Kuwait: Dependency and Class in a Rentier State (Florida University Press 1993) 125; Osman Salih, 'Kuwait Primary (Tribal) Elections 1975-2008: An Evaluative Study' (2011) 38(2) British Journal of Middle Eastern Studies 141, 144.

27 Jill Crystal, 'Public Order and Authority: Policing Kuwait' in Paul Dresch and James P Piscatori (eds), Monarchies and Nations: Globalisation and Identity in the Arab States of the Gulf (Bloomsbury Academic 2005) 176; Longva (n 24) 185; Lund-Johansen (n 15) 2, 32, 37 38; Beaugrand, Statelessness in the Gulf (n 25) 124-25; Beaugrand, Statelessness and Transnationalism (n 14) 149; Abbas Shiblak, 'Arabia's Bidoon' in Brad Blitz and Maureen Lynch, Statelessness and the Benefits of Citizenship: A Comparative Study (Geneva Academy of International Humanitarian Law and Human Rights and International Observatory on Statelessness 2009) 89; Jill Crystal, 'Public Order and Authority: Policing Kuwait' in Paul Dresch and James P Piscatori (eds), Monarchies and Nations: Globalisation and Identity in the Arab States of the Gulf (Bloomsbury Academic 2005) 176, 178.

28 Jérémie Gilbert, 'Nomadic Territories: A Human Rights Approach to Nomadic Peoples' Land Rights' (2007) 7(4) Human Rights Law Review 681, 681-716. 